\title{
Fate of Pierce's Disease Strains of Xylella fastidiosa in Common Riparian Plants in California
}

\author{
A. H. Purcell and S. R. Saunders, Department of Environmental Science, Policy and Management, University of \\ California, Berkeley 94720-3112
}

\begin{abstract}
Purcell, A. H., and Saunders, S. R. 1999. Fate of Pierce's disease strains of Xylella fastidiosa in common riparian plants in California. Plant Dis. 83:825-830.

The fate of strains of the bacterium Xylella fastidiosa that cause Pierce's disease of grapevines was investigated in 33 species of mostly perennial plants common in riparian habitats in northern coastal California grape-growing regions. Plants were inoculated in the field with needle puncture using cultured cells of $X$. fastidiosa as inoculum or inoculated in the laboratory with infective insect vectors (Graphocephala atropunctata). Populations of $X$. fastidiosa were highest in most plant species within 3 to 6 weeks of inoculation, followed by declines in populations of viable bacteria over the next 3 to 4 months. Homogenates of petioles of California black walnut (Juglans hindsii) and coffeeberry (Rhamnus californica) inhibited in vitro growth of X. fastidiosa, precluding culture of the bacterium from these plants. Big leaf maple (Acer macrophyllum), California buckeye (Aesculus californica), California blackberry (Rubus ursinus), coast live oak (Quercus agrifolia), elderberry (Sambucus mexicana), French broom (Genista monspessulanus), periwinkle (Vinca major), valley oak (Quercus lobata), and the grape rootstock Vitis rupestris supported systemic populations of $X$. fastidiosa that survived throughout the year outdoors in Napa Valley, California.
\end{abstract}

Additional keywords: sharpshooter, systemic movement

Strains of the bacterium Xylella fastidiosa that cause Pierce's disease (PD) of grapevines (Vitis spp.) can infect numerous species of plants, most without causing disease. Tests in the 1940s using vector transmission identified 91 of 116 tested species as hosts of the "Pierce's disease virus" (1). Later surveys detected X. fastidiosa in naturally occurring plants in northern California in an additional three species by serological assays, and in seven other species by culture of the bacterium $(13,14)$. In the eastern United States, $X$. fastidiosa has been detected in several plant species (9). More recently, a comparative study (7) characterized the fate of $X$. fastidiosa in grape ( $V$. vinifera $L$.) and four other weedy species that are important breeding hosts of the principal insect vectors of $X$. fastidiosa in California. The blue-green sharpshooter, Graphocephala atropunctata (BGSS), transmitted the bacterium to grape, Himalayan blackberry (Rubus procerus), mugwort (Artemisia douglasiana), and water grass (Echino-

Corresponding author: A. H. Purcell

E-mail: purcell@nature.berkeley.edu

Research was supported by grants from the North Coast Pierce's Disease Task Force and the American Vineyard Foundation.

Accepted for publication 17 May 1999.

Publication no. D-1999-0621-02R

(C) 1999 The American Phytopathological Society chloa crusgalli) with varying efficiencies. Maximum populations of $X$. fastidiosa were more than $100 \times$ lower in mugwort than in grape, and systemic movement of $X$. fastidiosa was detected only in blackberry and grape. In a companion study (6), a threshold population density of $X$. fastidiosa for acquisition by an efficient vector was approximately $\log 4 \mathrm{CFU} / \mathrm{g}$ of plant tissue, and the efficiency with which BGSS acquired the bacterium from plants increased as bacterial populations increased.

In coastal California, the incidence of PD is consistently highest along the margins of vineyards adjacent to riparian habitats that harbor overwintering vector populations $(3,4,11)$. In California, the spread of PD has long been thought (4) to occur primarily with the influx of vectors from habitats outside vineyards, rather than from grape to grape. One explanation offered for the apparent lack of significant secondary (grape to grape) spread of PD was that most late-season infections of $X$. fastidiosa do not survive the following winter in California (12). If this is true, then the early-season infections, established mostly by overwintered adults, are most critical in causing infections of $X$. fastidiosa that persist through subsequent years. The fate of $X$. fastidiosa in riparian plants that frequently serve as food hosts of the BGSS therefore may be important to the epidemiology of PD where this sharpshooter is the principal vector. Over three years of sweep-net sampling to evaluate host plant preferences of the BGSS, we compiled a list of the commonly occurring perennial plants in riparian habitats in Napa, Mendocino, Santa Cruz, and Sonoma counties in northern California (unpublished data). We report here our evaluations of the fate of $X$. fastidiosa in the most common riparian species of perennials in coastal northern California. We especially emphasized plants from which we consistently detected BGSS nymphs. To estimate the intraplant population distribution of $X$. fastidiosa, we attempted to culture the bacterium from portions of inoculated plants sampled at, or at various distances from, the point of inoculation. We tested the overwinter survival — and by default, the systemic colonization-of $X$. fastidiosa in some species where we had a sufficient number of plants confirmed as infected. During the course of our studies, we recognized the need to evaluate the impact of plant inhibitors on the growth of $X$. fastidiosa in vitro that may interfere with the interpretation of results from culture assays.

\section{MATERIALS AND METHODS}

Vector and mechanical inoculation. All test or insect-rearing plants were propagated in greenhouses that were continuously ventilated with charcoal-filtered air to maintain positive inside pressure to exclude insects from entering the greenhouses. The scientific names for all plants tested are given where first listed in Tables 1 through 4 or, if not included there, at first mention in the text, and follow the classification and nomenclature of the second edition of Jepson's Manual of California Flora (5). Grapevines (Vitis vinifera cvs. Pinot noir or Cabernet sauvignon) were propagated from seed or cuttings. Periwinkle (Vinca major) was propagated from rooted cuttings from a plant collected in Ashland, Oregon and tested negatively by repeated attempts to culture $X$. fastidiosa. California blackberry was propagated by layering or by cuttings from seedlings raised in the greenhouse. All other plants were grown from field-collected seeds from Napa or Sonoma Valleys.

We used separately two strains (designated here as CONN and STL) of X. fastidiosa isolated from PD-symptomatic grapevines near Yountville, California for all experiments. We inoculated plants in the field with cultured $X$. fastidiosa by pipetting a small drop of a turbid suspen- 
sion $(\approx \log 8$ cultured cells $/ \mathrm{ml})$ of $X$. fastidiosa in $\mathrm{pH} 7$ phosphate-buffered saline (PBS) onto a stem and probing the drop with a \#2 insect pin until we observed uptake from the drop. Needle inoculations of potted grape seedlings maintained in the greenhouse served as positive controls; inoculations with PBS served as negative controls.

The BGSS collected from field populations in Berkeley or Napa Valley and caged for 2 to 4 days on potted grapevines with Pierce's disease symptoms were used for most inoculations. It is likely that some of the BGSS were naturally infective with PD strains of $X$. fastidiosa. Vector inoculations used four BGSS caged on 5-cm lengths of stem in a greenhouse insectary for 2 to 5 days. The position of the cage on the plant was marked with tape after the insects were removed and plants were kept in a heated greenhouse. We used five to seven red-headed sharpshooters (Carneocephala fulgida) that had been reared in the laboratory on barley (Hordeum vulgare) to inoculate sedges (Cyperus spp.) after acquisition feeding of 4 or more days on alfalfa (Medicago sativa) infected with $X$. fastidiosa.

We mechanically inoculated plants in the field on 28 March; 27 and 30 April; 3, 7, 10, 17, and 24 May 1995; and 30 May 1996. All species tested in the field except for California rose, coyote brush, poison oak, snowberry, and spicebush were inoculated on more than one date. Vector inoculation of plants in the greenhouse proceeded throughout 1995 to 1997 , mostly from March through October. As positive controls, we inoculated in the field two potted grapevine seedlings with the same inoculum used for field plants and returned the grapevines to the greenhouse for later diagnosis of infection by $X$. fas tidiosa. We detected $X$. fastidiosa from all such positive controls except for one date, when the grapevines died before testing. All species tested with vector inoculation were repeated at least once except for cottonwood, poison hemlock, and sandbar willow. In one set of experiments with coffeeberry and walnut, five BGSSs per plant from populations normally free of $X$. fastidiosa were pretested by exposure to a healthy grape test plant $(1,6)$, transferred to a previously inoculated coffeeberry or walnut plant to acquire $X$. fastidiosa, then

Table 1. Culture of Xylella fastidiosa from riparian plants in the field following needle inoculation

\begin{tabular}{|c|c|c|c|c|}
\hline Species & No. tested & Positive (\%) & CFU/ga & Incubation (days) $^{\mathbf{b}}$ \\
\hline Arroyo willow, Salix lasiolepis ${ }^{\mathrm{c}}$ & 19 & 0 & $\ldots$ & $91-135$ \\
\hline Big leaf maple, Acer macrophyllum & 30 & 33 & $\log 4-6$ & $85-121$ \\
\hline Blue elderberry, Sambucus mexicana & 19 & 32 & $\log 6-7$ & $78-106$ \\
\hline California bay or laurel, Umbellularia californica & 25 & 0 & $\ldots$ & $113-128$ \\
\hline California black walnut, Juglans californica & 14 & 0 & $\ldots$ & $119-133$ \\
\hline California buckeye, Aesculus californica & 24 & 63 & $\log 4-6$ & $85-114$ \\
\hline California rose, Rosa californica & 8 & 38 & $\mathrm{ND}^{\mathrm{d}}$ & 96 \\
\hline Coast live oak, Quercus agrifolia & 22 & 0 & $\ldots$ & $106-135$ \\
\hline Coyote brush, Baccharis pilularis & 5 & 0 & $\ldots$ & 99 \\
\hline Fremont cottonwood, Populus fremontii & 11 & 0 & $\ldots$ & $99-121$ \\
\hline Oregon ash, Fraxinus latifolia & 18 & 0 & $\ldots$ & $113-114$ \\
\hline Poison oak, Toxicodendron diversilobum & 7 & 43 & $\log 4-6$ & 104 \\
\hline Red willow, Salix laevigata & 20 & 0 & $\ldots$ & $91-128$ \\
\hline Sandbar willow, Salix sessilifolia & 12 & 0 & $\ldots$ & $91-113$ \\
\hline Snowberry, Symphoricarpos albus & 7 & 57 & ND & 96 \\
\hline Spicebush, Calycanthus occidentalis & 27 & 0 & $\ldots$ & $25-60$ \\
\hline Valley oak, Quercus lobata & 23 & 35 & $\log 4-6$ & $113-159$ \\
\hline White alder, Alnus rhombifolia & 10 & 0 & $\ldots$ & $97-121$ \\
\hline Wild plum, Prunus sp. & 24 & 17 & $\log 6$ & $105-147$ \\
\hline
\end{tabular}

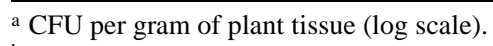

${ }^{\mathrm{b}}$ Days between inoculation and attempted culture.

c Some trees may have been yellow willow (S. lutea) but misidentified as arroyo willow.

d Not done.

Table 2. Culture of Xylella fastidiosa after 27 to 197 days following insect-vector (Graphocephala atropunctata) inoculation of plants in greenhouse

\begin{tabular}{|c|c|c|c|c|}
\hline Species $^{\mathbf{a}}$ & No. tested & Positive (\%) & $\mathrm{CFU} / \mathrm{g}^{\mathbf{b}}$ & Incubation (days) $^{\mathrm{c}}$ \\
\hline Big leaf maple & 14 & 29 & $\log 4-7$ & $113-121$ \\
\hline Blue elderberry & 9 & 33 & $\log 4-6$ & $123-133$ \\
\hline California bay or laurel* & 11 & 45 & $\log 4$ & $121-133$ \\
\hline California blackberry, Rubus ursinus & 7 & 100 & $>\log 6$ & 77-96 \\
\hline California buckeye & 12 & 17 & $\log 5$ & $109-123$ \\
\hline California coffeeberry, Rhamnus californica & 12 & 0 & $\ldots$ & 63-197 \\
\hline Coyote brush* & 15 & 27 & $\log 3-6$ & $98-111$ \\
\hline Fremont cottonwood* & 9 & 44 & $\log 4-6$ & 30 \\
\hline French broom, Genista monspessulana & 8 & 75 & $>\log 6$ & $85-240$ \\
\hline Greater periwinkle, Vinca major & 13 & 100 & $\log 8$ & $95-123$ \\
\hline Ivy, Hedera helix & 14 & 14 & $\log 3-5$ & $98-118$ \\
\hline Mexican tea, Chenopodium ambrosiodes & 9 & 0 & $\ldots$ & 31 \\
\hline Mugwort, Artemisia douglasiana & 12 & 42 & $\log 3-5$ & $51-52$ \\
\hline Nutgrass, Cyperus eragrostis & 19 & 16 & $\mathrm{ND}^{\mathrm{d}}$ & $107-135$ \\
\hline Poison hemlock, Conium maculatum & 8 & 13 & ND & 78 \\
\hline Poison oak & 6 & 17 & ND & $70-77$ \\
\hline Sedge, Cyperus acuminatus & 8 & 0 & $\ldots$ & $54-78$ \\
\hline Toyon, Heteromeles arbutifolia & 29 & 0 & $\ldots$ & $27-118$ \\
\hline Valley oak & 11 & 27 & $\log 5$ & $119-146$ \\
\hline
\end{tabular}

a * indicates species tested negatively in field experiments.

${ }^{\mathrm{b}} \mathrm{CFU}$ per gram of plant tissue (log scale).

${ }^{\mathrm{c}}$ Days between inoculation and attempted culture.

d Not done. 
transferred to a healthy grape test plant. Vector transmission was indicated by PD symptoms in grape test plants or by culture of $X$. fastidiosa from the inoculated grapevines after 6 to 12 weeks. We also attempted recovery of $X$. fastidiosa from vector-inoculated Cyperus acuminatus using five $C$. fulgida per plant, subsequently tested on grape for transmission of $X$. fastidiosa.

Assays for $\boldsymbol{X}$. fastidiosa. The methods for culturing $X$. fastidiosa (sample preparation, surface sterilization, periwinkle wilt-Gelrite [PWG] growth medium, and dilution plating) were as previously described (7). Briefly, approximately $0.1 \mathrm{~g}$ of plant samples (petioles, midveins of plants with sessile leaves, or stems) were weighed, surface sterilized, then aseptically rinsed and chopped into small $(<1$ $\mathrm{mm}$ ) pieces. The chopped sample was homogenized in $2 \mathrm{ml}$ of PBS and dilution plated (undiluted and two 100-fold dilutions) to estimate the numbers of cultivable bacterial cells. This method has a $95 \%$ Poisson (random) probability of detecting one or more CFU if the sample has a population of $300 \mathrm{CFU} / \mathrm{g}$. A sample from a Pierce's diseased grapevine in the greenhouse was included as a positive control each time that culturing was attempted. The characteristic appearance, growth rate, and growth pattern of colonies of $X$. fastidiosa were regarded as positive identification, but we tested selected cultures by polymerase chain reaction (PCR), using the methods and primers RST 31 and RST 33 as previously described (10). All such cultures of putative $X$. fastidiosa tested positively.

Samples from field-inoculated plants consisted of petioles immediately distal to the inoculated internode or stem segments adjacent to the inoculation scar when leaves were no longer present at the site (e.g., cottonwood, plum). Samples from BGSS-inoculated plants were pieces of stem or petiole that had been included in the cage. For both types of inoculation, samples of petioles distant from the site of inoculations were used to assay for systemic movement of the bacterium. Initially, we attempted to culture $X$. fastidiosa from inoculated plants 3 to 4 months after inoculation, but later, in experiments with some plant species, we assessed bacterial populations at various intervals following vector inoculation, beginning as soon as 4 days after placing vectors on test plants. For some experiments with red willow (Salix laevigata) and arroyo willow ( $S$. lasiolepis), we used PCR and culturing assays from samples of leaf midveins and a small $(1 \mathrm{~cm})$ segment of attached stem collected from the same plants at the same time.

Potted plants with infections confirmed by culture were maintained outdoors in screen cages in Oakville (Napa Valley) from December to March. Plants were then returned to the greenhouse for at least 3 months and retested for infection by culture.

Bacterial inhibitors in plants. We tested for the presence in plants of possible inhibitors of the in vitro growth of $X$. fastidiosa by aseptically processing, as described above, samples from uninoculated plants. We added $20 \mu \mathrm{l}$ of a suspension of $X$. fastidiosa $(\approx \log 8 \mathrm{CFU} / \mathrm{ml})$ to the homogenized samples and, as the control, to an equal volume $(2.1 \mathrm{ml})$ of PBS. These mixtures, from three separate samples for each species tested, were plated undiluted and as 100-fold dilutions. Colony growth and number were compared to that of the control.

\section{RESULTS}

Mechanical inoculations. Because populations of $X$. fastidiosa in grape take more than 4 weeks to peak under greenhouse conditions (7) and probably grow more slowly in field conditions, we waited for 3 to 4 months before attempting to culture $X$. fastidiosa from inoculated plants

Table 3. Detection of Xylella fastidiosa from plants inoculated by Graphocephala atropunctata in the greenhouse, where culturing was attempted after both short (from 4 to 33 days) and long (from 84 to 200 days) incubation periods after inoculation

\begin{tabular}{|c|c|c|c|c|}
\hline Species $^{\text {a }}$ & No. tested & Positive (\%) & $\mathrm{CFU} / \mathrm{g}^{\mathrm{b}}$ & Incubation (days) $^{c}$ \\
\hline Box elder, Acer negundo & 22 & 9 & $\log 4$ & $99-127$ \\
\hline Box elder & 19 & 47 & $\log 4-5$ & 26 \\
\hline White alder* & 17 & 0 & $\ldots$ & $107-109$ \\
\hline White alder* & 14 & 7 & $\log 4$ & 23-30 \\
\hline Coast live oak* & 20 & 20 & $\log 6$ & $98-123$ \\
\hline Coast live oak* & 7 & 29 & $\log 4$ & 28 \\
\hline Mule fat, Baccharis salicifolia & 10 & 0 & $\ldots$ & 100 \\
\hline Mule fat & 10 & 30 & $\log 4-7$ & 28 \\
\hline Oregon ash* & 11 & 27 & $\log 3$ & $113-146$ \\
\hline Oregon ash* & 10 & 50 & $\log 3-4$ & 22 \\
\hline Arroyo willow* & 18 & 0 & $\ldots$ & $84-103$ \\
\hline Arroyo willow* & 9 & 56 & $\log 3-4$ & $4-25$ \\
\hline Red willow* & 15 & 7 & $\log 3-4$ & $84-94$ \\
\hline Red willow* & 17 & 65 & $\log 4-6$ & 4-24 \\
\hline Stinging nettle, Urtica dioica & 8 & 0 & $\ldots$ & $102-200$ \\
\hline Stinging nettle & 13 & 8 & $\log 4$ & $6-33$ \\
\hline
\end{tabular}

a $*$ indicates species that tested negatively in field experiments.

${ }^{\mathrm{b}} \mathrm{CFU}$ per gram of plant tissue (log scale)

c Days between inoculation and attempted culture

Table 4. Survival of Xylella fastidiosa in plants infected by inoculation with Graphocephala atropunctata (blue-green sharpshooter) after overwinter exposures in outdoor cages, Oakville, California

\begin{tabular}{lccc}
\hline Species & No. tested & Still infected after winter (\%) & Date of culturinga \\
\hline Big leaf maple & 5 & 20 & July 1996 (vector inoculated) \\
Big leaf maple & 5 & 20 & June 1997 (mechanically inoculated) \\
California bay laurel & 5 & 20 & July 1996 \\
California blackberry & 14 & 29 & July 1996 \\
Coast live oak & 5 & 20 & July 1996 \\
French broom & 3 & 66 & July 1995 \\
Periwinkle, Vinca major & 5 & 00 & July 1997 \\
Vitis rupestris & 8 & 66 & August 1995 \\
Vitis rupestris & 6 & 605 & July 1997 \\
\hline
\end{tabular}

a Plants were inoculated and confirmed as infected with Xylella fastidiosa the previous spring or summer. 
in the field and almost as long in greenhouse tests using vectors. The 8 plant species that supported the multiplication of $X$. fastidiosa following needle inoculation of cultured bacterial cells and 11 species from which we did not culture $X$. fastidiosa are listed in Table 1. Some trees identified as arroyo willow (S. lasiolepis) may have been the closely similar yellow willow $(S$. confirm this conjecture after the fact.

Vector inoculation. We cultured X. fastidiosa from twice as many plant species inoculated by vector under greenhouse conditions as we did from the same species mechanically inoculated in field trials. Plant species from which we cultured $X$. fastidiosa in greenhouse trials following vector inoculation but failed to culture from mechanical inoculations in the field were arroyo willow, bay laurel, coast live oak, cottonwood, coyote brush, Oregon ash, red willow, and white alder (Tables 2 and 3). We were unable to propagate snowberry, spicebush, wild plum, and wild rose for testing in the greenhouse. None of the species that tested negatively in the greenhouse vector inoculations tested positively in field mechanical inoculations. Plants that we tested only by vector inoculation were box elder, California blackberry, coffeeberry, French broom, ivy, mugwort, mule fat, periwinkle, poison hemlock, stinging nettle, toyon, and sedges. $X$. fastidiosa multiplied in all but toyon. Umbrella sedge and poison hemlock plants from which we cultured $X$. fastidiosa were stunted, as previously reported (14). Stunted poison hemlocks died within 1 to 2 months after stunting was first noticeable. We failed to culture $X$. fastidiosa from Cyperus acuminatus or to recover the bacterium from grapevines exposed to red-headed sharpshooters that had been fed on $C$. acuminatus that had been inoculated 53 days earlier. Periwinkles in greenhouse experiments developed mild leaf scorch symptoms about 6 months

A

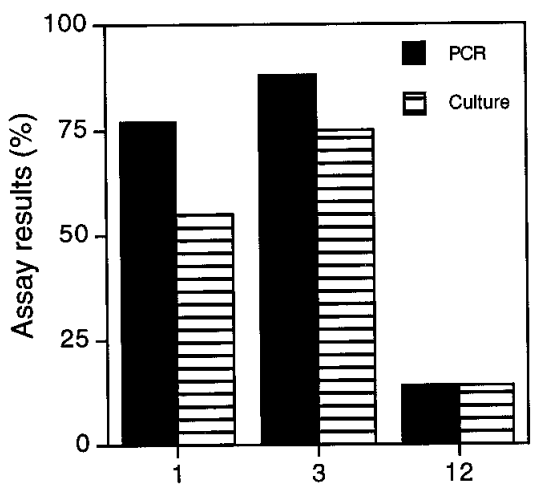

Weeks after inoculation lutea) or hybrids, but it was not possible to

after inoculation with $X$. fastidiosa. We have not noted leaf scorch in natural populations of periwinkle near PD outbreaks.

As indicated by the double entries for some plant species (Table 3), we recovered $X$. fastidiosa more frequently from plants when we isolated from them less than 5 weeks after inoculation. After we had consistently failed to isolate $X$. fastidiosa from willows, but other workers found positive PCR results for $X$. fastidiosa (Bruce Kirkpatrick, personal communication), we tested the idea that $X$. fastidiosa might multiply within vector-inoculated willows but die within a few months. We detected $X$. fastidiosa populations in red willow and arroyo willow as soon as 4 days after the beginning of vector inoculation ( $\log 3$ to 4 $\mathrm{CFU} / \mathrm{g}$ ), and populations had increased after 3 weeks to $\log 4$ to $6 \mathrm{CFU} / \mathrm{g}$, but we cultured $X$. fastidiosa from only 1 of 32 willows after 12 weeks (Fig. 1). Results from PCR were similar to culture in the frequency of detecting $X$. fastidiosa.

Systemic infections following vector (greenhouse) inoculation of French broom were demonstrated by culture from new plant growth that occurred after inoculation. Similarly, we found that $X$. fastidiosa in periwinkle spread into stems adjacent to the inoculated stem, and we cultured $X$. fastidiosa from California blackberry at three nodes from the inoculation site. We also cultured $X$. fastidiosa from big leaf maple petioles at three nodes distal to the inoculation site in both field (mechanical inoculation) and greenhouse (both mechanical and vector inoculation) experiments. In one trial with one plant each of buckeye, coast live oak, and valley oak, a successful culture from a vector-inoculated site was made after 4 months of incubation while a simultaneous attempt from a distal position on the same stem was negative. In field studies, we cultured $X$. fastidiosa from leaves between 30 and $60 \mathrm{~cm}$ from the site of (mechanical) inoculation in val-

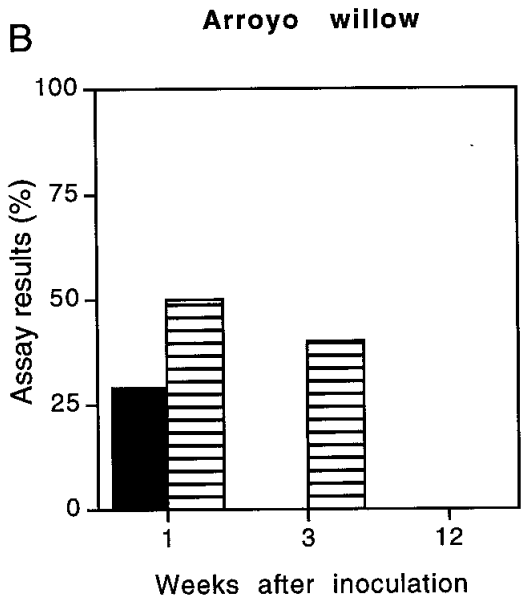

Fig. 1. Detection by polymerase chain reaction and culturing of Xylella fastidiosa in samples taken from stem and leaf midribs of (A) red willow and (B) arroyo willow inoculated by blue-green sharpshooter. ley oak. Positive cultures from new leaves in overwintered field inoculations of elderberry (including a stem basal to the inoculation site), buckeye, valley oak, and maple indicated that infections persisted and spread systemically in these species, although it is possible that newer natural infections of the sampled tissues had occurred during the second spring or summer. We did not inoculate California wild grape (Vitis californica), but cultured $X$. fastidiosa from 4 of 10 arbitrarily collected symptomless wild grape leaves from separate plants in September 1994. We observed mild to moderate marginal leaf scorch in $V$. californica in riparian habitats. The patterns of occurrence of symptomatic leaves along shoots of $V$. californica strongly suggest substantial systemic movement of $X$. fastidiosa in wild grape. However, we did not observe marginal scorching on more than about $30 \%$ of the leaves on any single vine or any die-back of symptomatic canes on this species.

Overwinter survival. For the five tree species in which we detected $X$. fastidiosa following mechanical inoculations in the field in 1995 (Table 1), we attempted to detect the survival of infections through the winter by culturing from new growth on these plants in the summer of 1996. We did not culture bacteria from wild plum, but the number of samples was small (four), and none of the sampled sites had been tested previously because prior sampling had removed the inoculated tissue. We detected $X$. fastidiosa in buckeye ( 7 of 18 samples were positive, including all four samplings of inoculation sites that had tested positive in 1995), and also in maple ( 2 of 25 samples, including one of two repeats of positive sites from 1995), elderberry ( 6 of 6 samples) and valley oak ( 2 of 18 samples, including one of two repeats of positive sites from 1995). The culture of $X$. fastidiosa from some inoculated sites more than a year after inoculation but not 3 to 4 months after inoculation probably reflects inefficiency in using culturing to detect active infections. However, it is possible that natural vector inoculation of the sampled plants during the same growing season as our second culturing attempts may have caused these infections.

All of the rooted cuttings of Vitis rupestris (St. George) that we inoculated with BGSS in 1994 developed marginal leafscorch symptoms of PD in the greenhouse, in contrast to symptomless uninoculated controls. We never observed marginal leaf scorch in $V$. rupestris in the field, despite the common occurrence of suckering of this widely used rootstock species after the grafted scion dies from PD. In August 1995, we failed to culture X. fastidiosa from these plants in repeated attempts after they had overwintered outdoors in Napa Valley (Table 4). The plants also remained free of PD symptoms. In a repetition of this experiment in 1996 to 1997 , we de- 
tected the overwinter survival of $X$. fastidiosa in four of the six $V$. rupestris that had been infected the previous year.

Bacterial inhibitors in plants. Black walnut and coffeeberry produced inhibiting factors in aqueous homogenates $(0.05 \mathrm{~g} /$ $\mathrm{ml})$ that prevented any growth of cultured cells of $X$. fastidiosa after $\log 2$ or $\log 4$ dilution. California bay laurel homogenates from petioles suppressed growth by $77 \%$ and from stems by $33 \%$. The degree of inhibition of the numbers of CFUs caused by the following plants was ash $64 \%$, cottonwood (petioles) 54\%, yellow willow $17 \%$, wild plum $16 \%$, and red willow $15 \%$. Inhibition of less than $15 \%$ was caused by homogenates of alder, arroyo willow, big leaf maple, box elder, California buckeye, coyote brush, elderberry, live oak, periwinkle, sandbar willow, and valley oak. Because of the strong inhibitors of X. fastidiosa present in homogenized walnut and coffeeberry, we attempted to recover $X$. fastidiosa from vector-inoculated walnut and coffeeberry plants with noninfectious vectors. We observed a single vector transmission of $X$. fastidiosa from coffeeberry in three experiments (14 test plants using 62 BGSS). There was no transmission after incubation times of 70 or 120 days. The successful transmission was 250 days after inoculation. One test plant in the trial at 120 days also became infected, but the pre-test plant had died, so this result could not be interpreted as acquisition from coffeeberry. These results suggest that $X$. fastidiosa can multiply within coffeeberry, but that chemicals released by homogenizing the plant during the culturing process prevent the growth of $X$. fastidiosa. Three attempts to transmit $X$. fastidiosa by vectors fed on previously vectorinoculated walnut using groups of five BGSS for 4 days were negative. Incubation in the walnuts had been for 2 (one plant) and 5 months (two plants). Of the 15 BGSS used, 14 survived the experiments.

\section{DISCUSSION}

Our results generally confirm observations from previous studies $(1,13,14)$ that $X$. fastidiosa multiplies in a variety of plants in natural environments, which readily explains why insects inhabiting riparian vegetation in California are often naturally infective with $X$. fastidiosa, even in environments far from susceptible crop plants $(1,2)$. Our results confirm the predictions of previous studies $(7,8)$ that most plant hosts of $X$. fastidiosa support much lower populations of the bacterium than do grape and other pathological hosts. It is likely that most hosts do not support extensive systemic movement of $X$. fastidiosa, but this is difficult to evaluate because of the irregular distribution of $X$. fastidiosa in woody plants. This problem is compounded in plants that support only low populations of the bacterium, where detection by culture is less reliable than in plants with high populations. The size and length of xylem elements can vary enormously within a single plant species and span an enormous range of differences among different species (16). It is possible that extensive intracellular multiplication is required to enable cell-to-cell movement. The likelihood of detectable systemic movement may vary among most plant species, just as infection efficiency varies among plant species.

Most of the plant species that we tested appear to support the growth of X. fastidiosa, but with much reduced multiplication and systemic movement compared to grape. Periwinkle and French broom supported both high populations and systemic movement of $X$. fastidiosa. These plants are sometimes abundant near vineyards with PD, but French broom is not a typical riparian species. None of the principal vectors of PD in California appear to favor French broom as a feeding host (unpublished data); however, it might be important as a long-term reservoir because it can harbor $X$. fastidiosa throughout the year. We consistently found nymphs and adults of two reported vector species, the meadow spittle bug, Philaenus spumarius (L.), and the leafhopper, Pagaronia triunata Ball, on French broom. These insects might maintain an infection cycle of $X$. fastidiosa that incorporates French broom as a host. We have found periwinkle to be a minor but consistent host for winter and spring feeding and some reproduction of the BGSS (unpublished data), so it may be an important reservoir host of $X$. fastidiosa.

The persistence of $X$. fastidiosa for only a few weeks in plants such as alder, ash, box elder, nettle, and willows indicates that detection methods first should be used within 1 to 3 weeks of inoculation to evaluate the fate of $X$. fastidiosa in potential hosts. For most species (e.g., maple and oaks) in which we detected multiplication after 3 to 4 months, attempts to culture $X$. fastidiosa after 3 to 4 weeks probably would have led to isolations from a higher percentage of the plants assayed. Greenhouse experiments did not detect $X$. fastidiosa in Himalayan blackberry or mugwort before 3 weeks (7), so 3 to 4 weeks is probably a reasonable incubation period for a greenhouse environment.

Chemical inhibitors in plant homogenates apparently are not a hindrance to detection of $X$. fastidiosa in most plant species, but this requires verification for each species of plant from which culture of the bacterium is attempted. Our results indicated that bacterial inhibitors in plant homogenates of coffeeberry that preclude the primary isolation of $X$. fastidiosa from plants by culturing do not prevent its growth within the plant to levels that can be acquired by insect vectors. Both xylemlimited bacteria and xylem sap-feeders confront the problem of nutrient sources that are extremely dilute. The absence of plant defensive compounds in xylem sap may be a compensating advantage (15).

The ability of $X$. fastidiosa to survive the winter in various plants may be important to the bacterium's long-term survival in areas with no or few overwintering adult vectors. Spittlebugs (family Cercopidae) and cicadas (Cicadidae) and some xylem sap-feeding leafhoppers (Cicadellidae: subfamily Cicadellinae) in North America generally overwinter as eggs or nymphs. All of the principal PD vectors in California $(3,4)$ overwinter in the adult stage and should be able to remain infectious with $X$. fastidiosa through the winter. The multiplication, systemic movement, and overwinter survival of $X$. fastidiosa in blackberry, French broom, and periwinkle indicate that these plants may be important permanent reservoirs of the bacterium in northern California. The overwinter recovery of the commonly used rootstock, $V$. rupestris, indicates that this or other rootstocks with similar properties may be useful in breeding rootstocks that can be regrafted after removing PD-affected scions. Our studies were conducted during unusually mild winters (1995 to 1997). Winters with more severe sub-freezing temperatures might reduce the survival rate of $X$. fastidiosa (12), perhaps even in evergreen plants such as California blackberry and periwinkle.

For categorizing the importance of various plants as reservoir hosts for vector acquisition, we propose three host categories to describe the fate of $X$. fastidiosa in various plants.

(i) Propagative or nonpropagative host (X. fastidiosa multiplies or does not multiply). Plants that develop populations of viable bacterial cells exceeding the $\log 4$ $\mathrm{CFU} / \mathrm{g}$ threshold for acquisition by an efficient vector (8) would be the most significant potential reservoirs. Higher populations up to a level exceeding $\log 8 \mathrm{CFU} / \mathrm{g}$ would increase acquisition efficiency (8). The populations of $X$. fastidiosa supported in plants ranged widely among the plant species in our study.

(ii) Systemic or nonsystemic host $(X$. fastidiosa moves from one xylem element to another or does not). Systemic movement decreases the dependence of $X$. fastidiosa on vector activity to expand in time and space and increases the capacity of plants to serve as inoculum sources.

(iii) Pathological or nonpathological host (measurable distress caused by infection). For example, PD strains that cause disease in grape cause no obvious harm in white alder. There is no evidence that nonpropagative hosts can be systemic or pathological hosts. A pathological host may not live as long or grow as quickly as hosts that are not harmed.

Environmental conditions probably influence the bacterium's rate of multiplication, intraplant movement, and winter survival. Symptoms of PD can appear in grape in a greenhouse environment in 6 to 
10 weeks; whereas, outdoors in California, 4 to 5 months are required. Temperature effects on bacterial growth might explain these differences but, to our knowledge, the influences of temperatures on the growth of $X$. fastidiosa in grape have not been measured directly. Our use of vectorinoculated plants in a greenhouse had the advantage of maximizing the probability of detecting multiplication of $X$. fastidiosa but may have identified species as hosts that effectively are not hosts under most natural conditions. The populations of $X$. fastidiosa detected in field experiments may be more realistic than greenhouse studies, but mechanical inoculations may introduce other artifacts in infecting woody stems. Dilution plating, taking into account the effects of plant inhibitors of $X$. fastidiosa, appears to provide the most useful epidemiological data on populations of $X$. fastidiosa in plants. PCR and immunological assays do not estimate the numbers of viable cells in plants, a property that is fundamentally important to the bacterium's persistence in nature and its role in plant diseases.

Propagative and systemic hosts have the greatest potential to serve as sources for vector acquisition of $X$. fastidiosa, but when and how often potential vectors feed on such plants should be equally important. For example, poison hemlock is an annual that typically germinates in fall or winter in California and begins to senesce in late spring, depending on temperature and soil moisture. Temperatures during late fall through early spring may be too cool for the adequate multiplication and movement of $X$. fastidiosa to enable vector acquisition until late spring. We have rarely detected the BGSS or other xylem feeders on poison hemlock in northern California, and then only during February to early April (unpublished data). Thus, even a high natural infection rate of poison hemlock and data showing that it is a propagative, systemic host would not be convincing evidence that it played a significant epidemiological role in PD. Therefore, the sizes of $X$. fastidiosa populations in natural vegetation must be combined with data on vector feeding preferences to estimate the epidemiological impact of particular plant species as a reservoir of $X$. fastidiosa.

Strain variation may also play a role in PD epidemics. Our studies utilized two PD strains from northern California. Other PD strains might differ in ability to colonize various host species.

\section{ACKNOWLEDGMENTS}

We thank M. D-C Hendson for providing PCR results; M. Hawkins, J. Yang, and A. Mogi for technical assistance; and D. Johnson and Beringer Vineyards for providing access to field sites.

\section{LITERATURE CITED}

1. Freitag, J. H. 1951. Host range of Pierce's disease virus of grapes as determined by insect transmission. Phytopathology 41:920-34.

2. Freitag, J. H., and Frazier, N. W. 1954. Natural infectivity of leafhopper vectors of Pierce's disease virus of grape in California. Phytopathology 44:7-11.

3. Goodwin, P., and Purcell, A. H. 1992. Pierce's disease. Pages 76-84 in: Grape Pest Management, 2nd Edition. University of California, Division of Agriculture and Natural Resources, Oakland.

4. Hewitt, W. B., Frazier, N. W., and Freitag, J. H. 1949. Pierce's disease investigations. Hilgardia 19:207-64.
5. Hickman, J. C., ed. 1993. The Jepson Manua of Higher Plants of California. University of California Press, Berkeley.

6. Hill, B. L., and Purcell, A. H. 1995. Acquisition and retention of Xylella fastidiosa by an efficient vector. Phytopathology 85:209-12.

7. Hill, B. L., and Purcell, A. H. 1995. Multiplication and movement of Xylella fastidiosa within grape and four other plants. Phytopathology 85:1368-72.

8. Hill, B. L., and Purcell, A. H. 1997. Populations of Xylella fastidiosa in plants required for transmission by an efficient vector. Phytopathology 87:1197-201.

9. Hopkins, D. L., and Adlerz, W. C. 1988 Natural hosts of Xylella fastidiosa in Florida Plant Dis. 72:429-31.

10. Minsavage, G. V., Thompson, C. M., Hopkins, D. L., Leite, R. M. V. B. C., and Stall, R E. 1994. Development of a polymerase chain reaction protocol for detection of Xylella fastidiosa in plant tissue. Phytopathology 84:456-61.

11. Purcell, A. H. 1975. Role of the blue-green sharpshooter, Hordnia circellata, in the epidemiology of Pierce's disease of grapevines. Environ. Entomol. 4:745-52.

12. Purcell, A. H. 1981. Vector preference and inoculation efficiency as components of resistance to Pierce's disease in European grape cultivars. Phytopathology 71:429-35.

13. Raju, B. C., Goheen, A. C., and Frazier, N. W 1983. Occurrence of Pierce's disease bacteria in plants and vectors in California. Phytopathology 73:1309-13.

14. Raju, B. C., Nomé, S. F., Docampo, D. M., Goheen, A. C., Nyland, G., and Lowe, S. K. 1980. Alternative hosts of Pierce's disease of grapevines that occur adjacent to grape growing areas in California. Am. J. Enol. Vitic. 31:144-8.

15. Raven, J. A. 1984. Phytophages of xylem and phloem: a comparison of animal and plant sap-feeders. Adv. Ecol. Res. 13:135-234.

16. Zimmermann, M. M. 1983. Xylem Structure and the Ascent of Sap. Springer-Verlag, Berlin. 